\title{
Photochemical Efficiency during the Establishment and Consolidation Phases of in Vitro Pinus radiata Micrograft Made from Scions of Different Ontogenetic Age
}

\author{
María E. Materán1, Patricia L. Sáez#, Manuel Sánchez-Olate², León A. Bravo³, \\ Roberto Rodríguez ${ }^{4}$, Darcy Ríos ${ }^{2}$, Rafael E. Coopman ${ }^{5 *}$ \\ ${ }^{1}$ Centro Biotecnológico de Guayana, Universidad Nacional Experimental de Guayana, Guayana, Venezuela \\ ${ }^{2}$ Facultad de Ciencias Forestales, Departamento de Silvicultura y Laboratorio Cultivo de Tejidos Vegetales, \\ Centro de Biotecnología, Universidad de Concepción, Casilla 160-C, Concepción, Chile \\ ${ }^{3}$ Laboratorio de Fisiología y Biología Molecular Vegetal, Instituto de Agroindustria, Departamento de Ciencias \\ Agronómicas y Recursos Naturales, Facultad de Ciencias Agropecuarias y Forestales and Center of Plant, Soil \\ Interaction and Natural Resources Biotechnology, Scientific and Technological Bioresource Nucleus, \\ Universidad de La Frontera, Casilla 54-D, Temuco, Chile \\ ${ }^{4}$ Departamento de Biología de Organismos y Sistemas, Facultad de Biología, Universidad de Oviedo, Oviedo, \\ España \\ ${ }^{5}$ Laboratorio de Ecofisiología para la Conservación de Bosques, Instituto de Conservación, Biodiversidad y \\ Territorio, Facultad de Ciencias Forestales y Recursos Naturales, Universidad Austral de Chile, Casilla 567, \\ Valdivia, Chile \\ Email: ${ }^{\text {rafael.coopman@gmail.com }}$
}

Received 6 January 2015; accepted 23 January 2015; published 26 January 2015

Copyright (C) 2015 by authors and Scientific Research Publishing Inc.

This work is licensed under the Creative Commons Attribution International License (CC BY).

http://creativecommons.org/licenses/by/4.0/

(c) (i) Open Access

\section{Abstract}

The aim of the present study was to evaluate the applicability of maximal photochemical efficiency of photosystem II (Fv/Fm) as an early estimate of $P$. radiata micrografts viability coming from different position (basal vs. apical) in the ortets. We hypothesize that $\mathrm{Fv} / \mathrm{Fm}$ variation is a good indicator of micrograft's viability and phenological stage during micrograft development. The micrografts were established in QL medium supplemented whit $0.1 \mathrm{mg} \cdot \mathrm{L}^{-1} \mathrm{IBA}$ and $1 \mathrm{mg} \cdot \mathrm{L}^{-1} \mathrm{BAP}$ and cultured at $25^{\circ} \mathrm{C} \pm 2^{\circ} \mathrm{C}$ and $80 \mu \mathrm{mol}$ photons $\mathrm{m}^{-2} \cdot \mathrm{s}^{-1}$ of photosynthetic active radiation by $16 \mathrm{~h}$ per day. During the establishment and consolidation phase, we found significant differences in Fv/Fm with respect to time and buds positions provenience. During establishment, basal shoot tips have

\footnotetext{
*These authors contributed equally to this work.

"Corresponding author.
}

How to cite this paper: Materán, M.E., et al. (2015) Photochemical Efficiency during the Establishment and Consolidation Phases of in Vitro Pinus radiata Micrograft Made from Scions of Different Ontogenetic Age. American Journal of Plant Sciences, 6, 228-239. http://dx.doi.org/10.4236/ajps.2015.61026 
lower Fv/Fm than apical shoot tips, which agrees with the lowest viability (35\%). However, during the consolidation phase, the trend changed and basal shoot tips presented higher Fv/Fm than apical shoot tips and showed an increase in ETR and NPQ, with respect to apical shoots and ortet. Although the measurement of fluorescence parameters implies the insertion of the fluorometer sonde in vitro, this implies aseptic considerations, but always conveies a contamination risk. We conclude that fluorescence (Fv/Fm, ETR, NPQ) can be indicators of the micrograft's development according to the shoot tips position in the ortet and can be useful early-indicators of the scions' physiological condition during micrograft transition from establishment to consolidation.

\section{Keywords}

\section{Maximum PSII Photochemical Efficiency, Micrograft, P. radiata}

\section{Introduction}

Pinus radiata $\mathrm{D}$. Don is one of the most important forestry species in the world in terms of annual wood production, with almost $25 \%$ of the world's production [1]. Today, this production depends on the ability to generate selected clones in the short term. However, as in many woody species, in Pinus radiata, there is a decline in morphogenetic ability across maturation. Therefore, upgrading forestry programs face the problem of selecting interesting traits during the mature age, while vegetative propagation is only possible during juvenile phases of development [2]. Thus, the decrease of morphogenic capacity with the ontogeny of the source material [3], affect among others the rooting ability of plant tissue [4] being often a barrier for plant multiplication or regeneration. Several studies conducted in Pinus sp. indicate an ontogenetic gradient of shoot tips morphogenic competence, determined by the vertical localization in the tree crown, where basal meristematic shoot tips present higher morphogenic capacities than apical ones [5]-[7]. It has been suggested that the decline in morphogenic capacity could be due to the loss in competence at the cellular level and it is highly likely that this phenomenon causes changes in gene transcription [8]. In vitro propagation methods may induce reinvigoration of advanced physiological tissue and renewal of ontogenetically adult $P$. radiata [3] [6], and in this way avoid the problems associated to the lost of morphogenic capacity. This reinvigoration includes anatomical, molecular and epigenetic changes which reflect characteristic juvenile individual's protein patterns, DNA methylation and polyamine content [6] [9]. Altogether, the reversion of several adult phenotypic traits towards more juvenile stages and the recovery of tissue morphogenic capabilities allow the cloning of selected adult trees [6] [9] [10]. One tissue reinvigoration techniques is the in vitro micrograft, which has been tested to reinvigorate ontogenetically adult vegetative buds on juvenile rootstocks [11] and can be a solution for cloning adult trees of several species, in which sprouts present deficient rooting and lack of vigor [3] [4].

It is known that during plant ontogenetic development, apical meristems exhibit significant morphophysiological changes, which reflect modifications in cellular competence to perceive or respond to external and internal signals, such as growth regulators [12]-[14] and environmental conditions [15]-[17]. These variations in cell sensitivity induce modifications in the capability to form adventitious buds and roots, but also involve changes in leaf anatomy, growth rates and photosynthetic functioning [4] [16]. Photosynthetic capacity has been commonly considered as plant overall performance indicator [18]-[20]. Light energy absorbed by chlorophyll can drive charge separations at photosystem II (PSII) reaction centers, triggering photosynthetic electron transport, which mostly drive carbon uptake. These reactions can be probed by chlorophyll $a$ fluorescence measurements through a process called photochemical quenching. In this context, fluorescence measurement has become a physiological tool commonly used to evaluate plant stress responses [15] [21]. Specifically, maximal photochemical efficiency of PSII (Fv/Fm) is a parameter that quantifies the fraction of absorbed light that is used in photochemistry after a dark period long enough to obtain all PSII reactions centers to reach an open state (reaction center reduced and acceptors completely oxidized), allowing the determination of the maximal photochemical light use capacity [22]. Hence, Fv/Fm has been commonly assumed as a proxy of photosynthetic capacity, reflecting the photosynthetic apparatus condition and at the same time is considered an ideal monitor of plant health and viability [18] [20] [21] [23]-[25]. Recently chlorophyll fluorescence has become a common tool to assess the photosynthetic performance of in vitro cultured plants [26]-[29]. Thus, [30] reported higher photo- 
synthesis rates in juvenile and rejuvenated than adult in vitro grown Sequoia sempervirens shoots. Photosynthetic performance has also been positively correlated with growth rates and survival of in vitro plants and with their viability to establish in ex vitro conditions [31] and has been used as an indicator of better in vitro acclimatization treatments [26]. We hypothesize that variations in fluorescence parameters such as Fv/Fm, ETR and NPQ are good indicators of micrograft's viability and phenological stage. Accordingly, we inquire into the effects of the position from which the scion is obtained (basal vs. apical) in the ortet and the utility of fluorescence as an early estimate of $P$. radiata micrografts viability. To our knowledge, this is the first study that specifically addresses the early prediction of micrograft viability through the detection of scion's photochemical capacity along in vitro reinvigoration process.

\section{Materials and Methods}

\subsection{Plant Material}

Fresh rootstocks coming from certified $P$. radiata seeds were obtained. Plantlets were cultivated in vitro by germinating seeds in QL medium [32] free of growth regulators and with macroelements diluted to $25 \% \mathrm{v} / \mathrm{v}$ of the original concentration. In order to prepare the rootstock, after 30 days of cultivation, the plantlets were extracted and root system and needles were eliminated at collar and cotyledonary needles insertion level, respectively. The scions were obtained from caulinary apexes coming from the lower and apical quarter portions of 9year-old and ca. $8.8 \mathrm{~m}$ tall P. radiata crowns (hereafter basal and apical, respectively. Figure 1(A) and Figure 1 (B)). Trees used for scions collection were part of the Genetic improvement program of the Fletcher Challenge
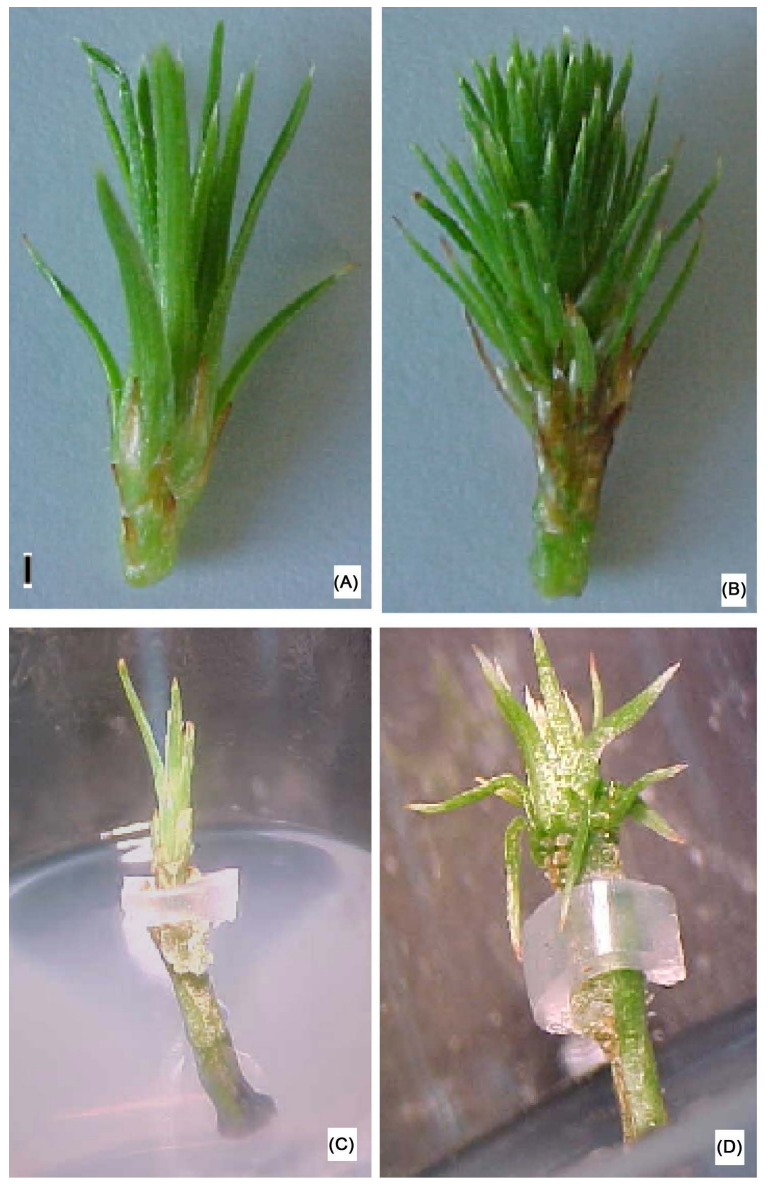

Figure 1. Morphology of vegetative shoot tips used as scions in the micrografts and in vitromicrograft developmental stages. Shoot tips from the apical portion (A), shoot tips from the basal ortetportion (B); micrografts during the establishment (C) and consolidation phases (D). Vertical black bar in A represents $1 \mathrm{~mm}$ length. 
(New Zealand) and Forestal Bio-Bio (Chile) Forest companies. The superficial scion asepsis began with the immersion of shoot tips in a solution of Captan ${ }^{\circledR}\left(2 \mathrm{mg} \cdot \mathrm{L}^{-1}\right)$ for $15 \mathrm{~min}$, followed by a washing with sterile distilled water. Under laminar flow chamber conditions, shoot tips were submerged in diluted ethanol $20 \%(\mathrm{v} / \mathrm{v})$ for $10 \mathrm{~s}$, followed by a washing with sterile distilled water. Then, scions were immersed in a solution composed by sodium hypochlorite $2.5 \%$ (v/v) and $100 \mu \mathrm{l}$ of Tween-20 for $20 \mathrm{~min}$, followed by 3 washings with sterile distilled water for 3, 4 and $5 \mathrm{~min}$, respectively. Finally, scions were maintained until their use in a benomile plus cystein solution, both of $50 \mathrm{mg} \cdot \mathrm{L}^{-1}$, acting as a fungicide and antioxidant, respectively.

\subsection{Micrograft Technique}

The micrografts were made using the wedge grafting method proposed by [3]. Briefly, the rootstocks were beheaded below the insertion point of the cotyledonary needles, and then these caulinary segments were cut by it longitudinal axis $3 \mathrm{~mm}$ from the apical part. In laminar flow chamber conditions and under an optical magnifying glass, needles of the scions were cut in order to obtain $2 \mathrm{~mm}$ long apexes. Then, in its basal portion, 2 "v"-cuts were made, forming a wedge to insert the scion in the rootstock's crevice. The contact between scion and rootstock was maintained with a sterile silicon rings, obtained from transversal cuts of $5 \mathrm{~mm}$ diameter silicon tube (Figure 1(C) and Figure 1(D)). Finally, micrografts were established in $50 \mathrm{ml}$ test tubes containing 15 $\mathrm{ml}$ of QL medium supplemented whit $0.1 \mathrm{mg} \cdot \mathrm{L}^{-1}$ indole butyric acid (IBA), $1 \mathrm{mg} \cdot \mathrm{L}^{-1}$ bencil aminopurine (BAP) and $30 \mathrm{~g} \cdot \mathrm{L}^{-1}$ sucrose. Growth chamber conditions during micrografts development were: $24^{\circ} \mathrm{C} \pm 2^{\circ} \mathrm{C}$ air temperature, photosynthetic photon flux density (PPFD) at scions level $80 \mu \mathrm{mol} \cdot \mathrm{m}^{-2} \cdot \mathrm{s}^{-1}$ by $16 \mathrm{~h}$ per day, and $60 \%$ air relative humidity.

\subsection{Viability, Establishment and Consolidation}

The viability was assessed visually according [9] and [3], hence if micrograft remained green without oxidative damage and turgid was considered viable. The establishment phase time was considered from the total micrografts initially introduced in vitro and remained viable, before scion-rootstock callus formation. The consolidation phase started with micrografts that remains viable and with scion-rootstock callus formation. The micrografts percentage reaching this phase was determined from those that survived the establishment phase.

\subsection{Maximal Photochemical Efficiency of PSII}

Fluorescence signals were measured by a pulse-amplitude modulated fluorometer (FMS 2, Hansatech, U.K). According to the terminology of [33], minimal fluorescence (Fo) was determined by applying a weak modulated light $\left(0.4 \mu \mathrm{mol}\right.$ photons $\left.\mathrm{m}^{-2} \cdot \mathrm{s}^{-1}\right)$ and maximal fluorescence (Fm) was induced by a short pulse $(0.8 \mathrm{~s})$ of saturating light $\left(9000 \mu \mathrm{mol}\right.$ photons $\left.\mathrm{m}^{-2} \cdot \mathrm{s}^{-1}\right)$. Maximal photosystem II photochemical efficiency (Fv/Fm), was estimated as described by Schreiber et al. (1994) where Fv $=$ Fm - Fo. Before fluorescence measurements, the whole ortet was dark adapted for $45 \mathrm{~min}$, with a black $0.2 \mathrm{~mm}$ thickness polietilene cover, in order to obtain open reactions centers through the oxidation of PSII primary acceptors. Shoot tips were labeled in both the apical and basal quarter portions of the ortets (0.0 - 2.2 and 6.6 - $8.8 \mathrm{~m}$ tall, respectively) and then Fv/Fm was subsequently measured. Once the micrografts were undertaken, Fv/Fm measurements were performed in vitro every ca. 2 days for each micrograft until their consolidation assessment (60 days after being cultivated). Additionally, the electron transport rate (ETR) was calculated at PPFD of $75 \mu \mathrm{mol} \mathrm{m} \mathrm{m}^{-2} \cdot \mathrm{s}^{-1}$ according to [24] as: ETR $=0.84 \times$ $\Phi P S I I \times$ PPFD $\times 0.5$. Where the factor 0.84 is the mean value of absorbance for green leaves, and the factor 0.5 assumes that the efficiency of both photosystems is equal and that radiation is equally distributed between them. The non-photochemical quenching (NPQ) was calculated as: (Fm - Fm)/Fm' ([21]).

\subsection{Data Analysis}

Generalized Lineal Models (GLM) and deviance analyses were used to compare the viability, establishment and consolidation percentages assuming Binomial error distribution [34] of 25 replicates where the experimental unit was the micrograft. The following analyses were conducted in plants that survived, using a completely random design with 10 replicates. For continuous variables, differences between apical and basal shoot tip provenance within each in vitro culture phases, were compared by one-way ANOVAs and the post hoc Tukey-test $(P<$ 0.05). Normality and homogeneity of variance were evaluated by Kolmogorov-Smirnov test $(P<0.05)$ and Le- 
vene $(P<0.05)$ tests. When appropriate, variables were transformed to follow the former assumptions [35]. Analyses were performed using Statistica software (Version 6, 2001, StatSoft, Tulsa, OK).

\section{Results and Discussion}

The micrograft's viability varied between vertical positions of shoot tips in the ortet. Micrografts made from apical shoot tips shows higher viability than basal ones $(P=0.029$; Figure 2, statistical details in Table 1 supplementary material). Thus, the $35 \%$ lower establishment of basal shoot tips may be due to several reasons; among them the effectiveness of asepsis of plant tissues introduced in in vitro conditions usually have a deep impact in their viability [36]. In this context, is important to note the different morphology exhibited between apical and basal scions (Figure 1(A) and Figure 1(B)). Apical scions present longer and less compact needles (Figure 1(A)). This may favor disinfection efficiency inducing greater micrograft viability and therefore establishment. On the contrary, basal scions showed evidently higher abundance, aggregation and shorter needles (Figure 1(B)). Otherwise, the concentrations of growth regulators in the shoot tips vary depending on their position in the ortet. [37] Reported higher concentration of auxins and cytokinins in apical shoot tips than basal ones, which may improve tissue responses to the in vitro introduction, specifically during $P$. radiata micrograft establishment [38].

Despite apical scions showed a higher micrografts establishment than basal ones, those differences fade out during the micrograft consolidation reaching in average 39\%. Commonly, the development of shoot tips and scion meristematic activity expressed as growth rates are key factors that determine micrograft success [3] [5]. The decrease in vigor and adventitious organs formation capacity are responses associated with the tissue maturation stage [4]. Hence, basal scions must present higher morphogenic capacities than apical ones, because their younger ontogenetic age determined by the proximity to the mother cell located at the collar of the ortet [5] [6]. In the consolidation phase we found that juvenile traits of ontogenically young tissues can be preserved in basal scions. The fact that maturity takes place in the periphery of tree crowns; in chronologically young but ontogenically older tissues, was reflected by the decrease of consolidation percentage of apical scions respect to establishment $(P=0.024$; Figure 2). However, the final grafting efficiency for apical scions was $20 \%$ and basal scions only $6 \%$. Therefore, this confirms that micrografting is a suitable strategy to reinvigorate old ontogenetic tissues in $P$. radiata.

Regarding to maximal photochemical efficiency, significant differences in shoot tips Fv/Fm values were detected between the establishment and consolidation phases (Figure 3, statistical details in Table 2 supplementary material). Only during the first day of in vitro introduction, a decrease in $\mathrm{Fv} / \mathrm{Fm}$ was observed in basal scions ( $P=0.01$; Figure 3). Such small Fv/Fm reduction could be attributable to the physiological stress imposed by the excision from ortet, and then the in vitro introduction [39] [40]. Despite this, we find a fast scions Fv/Fm recovery, due to the in vitro culture conditions, which also exert the surpass of $\mathrm{Fv} / \mathrm{Fm}$ values measured in the ortet

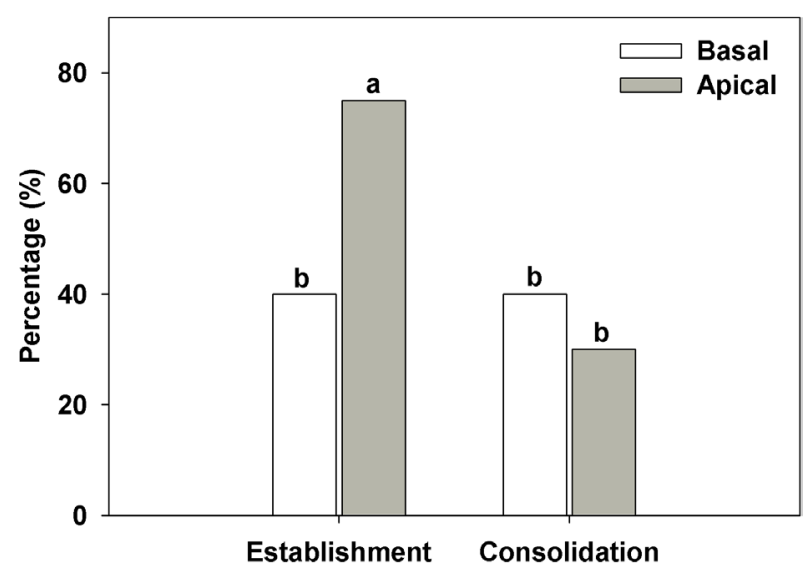

Figure 2. Effect of shoot tips provenance in the ortet on percentage of establishment and consolidation of $P$. radiate micrografts. Shoot tips were collected from the basal and apical quarter of the ortet crown (9-year-old and ca. $8.8 \mathrm{~m}$ tall). Different letters indicates significant differences $(\mathrm{n}=20$, Wald stat, $P<0.05)$. 


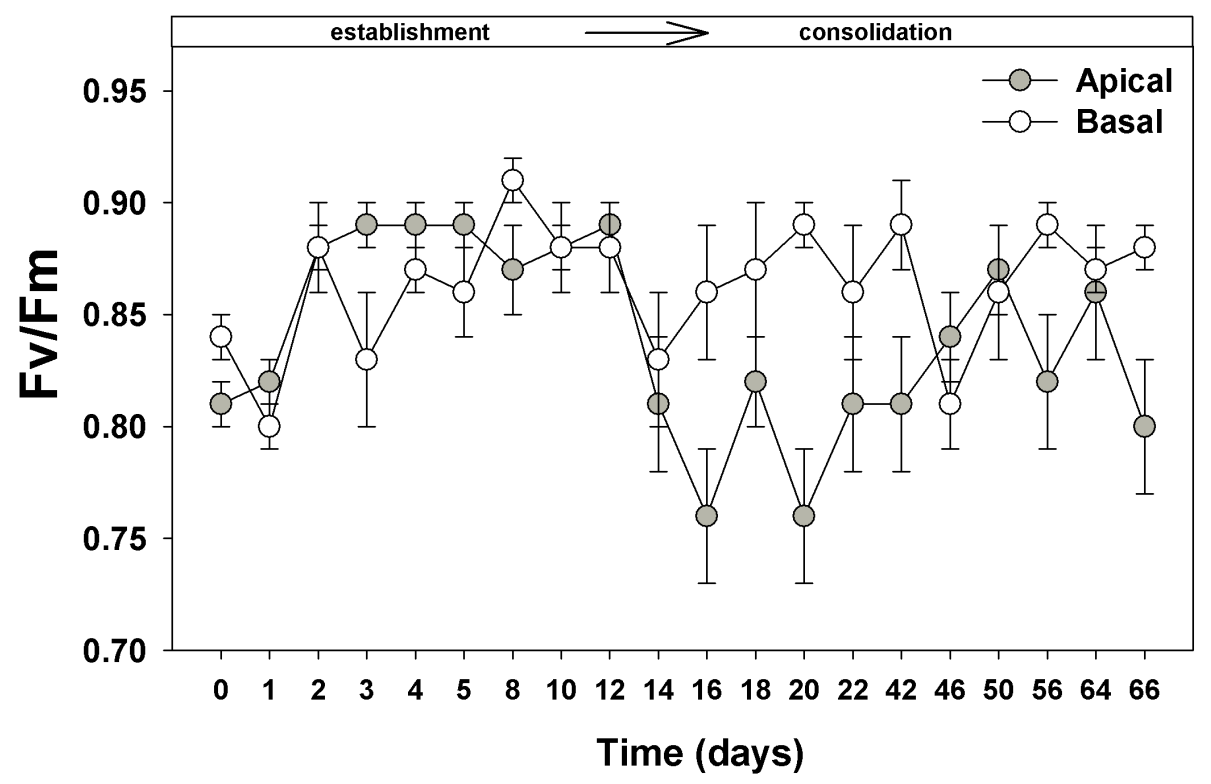

Figure 3. Photosystem II maximal photochemical efficiency (Fv/Fm) of micrografts made from basal and apical shoot tips during in vitro establishment and consolidations phases. Shoot tips were collected from the basal and apical quarter of the adult $P$. radiate ortet crown (9-year-old and ca. $8.8 \mathrm{~m}$ tall). Mean \pm SE $(\mathrm{n}=10)$.

from the second day. During the first two weeks of in vitro culture, in average basal scions had a more variable Fv/Fm and sometimes slightly lower than apical ones $(P=0.045$; Figure 3$)$, which agreed with their lowest micrograft establishment (Figure 2). Thereafter, during the beginning of consolidation phase (around 13 day), the trend was reversed. Apical scions significantly decreased their Fv/Fm $(P<0.001$; Figure 3$)$, even to lower values than those observed in the ortet. On the contrary, along in vitro culture basal scions displayed higher $\mathrm{Fv} / \mathrm{Fm}$ during consolidation than apical ones $(P<0.001$; Figure 3$)$.

Additionally, during establishment PSII light energy partitioning of apical and basal scions were similar (lowest $P=0.435$; Figure 4, statistical details in Table 3 supplementary material). Conversely during consolidation these ontogenetic younger (basal) and more plastic scions were able to increase ETR in 43\% and NPQ in $100 \%$ ( $P=0.046$ and $P=0.019$, respectively). The latter both are save valves to dissipate higher PSII excitation pressures, which are indicators of higher capacity to handle and take advantage of higher PPFDs. Increments by more than $100 \%$ in thermal dissipating capacity of excess light energy has been reported in ventilated vessels respect to traditional in vitro condition [29]. Regardless of vertical location in the ortet, shoot tips show similar values of ETR, indicating that in the field they display similar capacities to conduct absorbed light forwards photochemical processes. Interestingly, apical shoot tips in the ortet exhibited higher NPQ, therefore higher capacity to safely dissipate the excess absorbed energy as heat. A commonly response to high light is the increment in xanthophyll pool size (VAZ), allowing them manage the excess of absorbed light by means of heat dissipation [41] [42]. Together, these parameters could determine a greater ability to withstand the stress of transfer to ex vitro conditions [31] and may therefore be an indicator of greater potential physiological performance once a micrograft coming from basal section in the ortet is consolidated. Unfortunately, the low efficiency of micrografting of these basal scions is a big constraint for a reinvigoration program. Further studies on the behavior of these micrografted plants during transference to ex-vitro conditions are needed to fully address this problem.

The different responses among in vitro culture phases suggest that it is more feasible to establish micrografts in vitro from apical shoot tips than that from basal shoot tips. Hence they are physiologically younger, and theoretically they are synthesizing auxins and therefore are able to faster cellular differentiation and division, favoring rapid adaptation to in vitro conditions [13] [14] [37] [43]. This was reflected in a higher viability and photochemical efficiency during establishment. Basal shoot tips, even though they are ontogenetically younger, they are physiologically and chronologically older, have lower endogenous auxins concentration, and slower cellular de-differentiation rates [13] [14] [37]. However, once basal scions are established, they achieve greater consolidation, concomitant with greater Fv/Fm at the end of this phase, concomitantly with greater photochemical ca- 


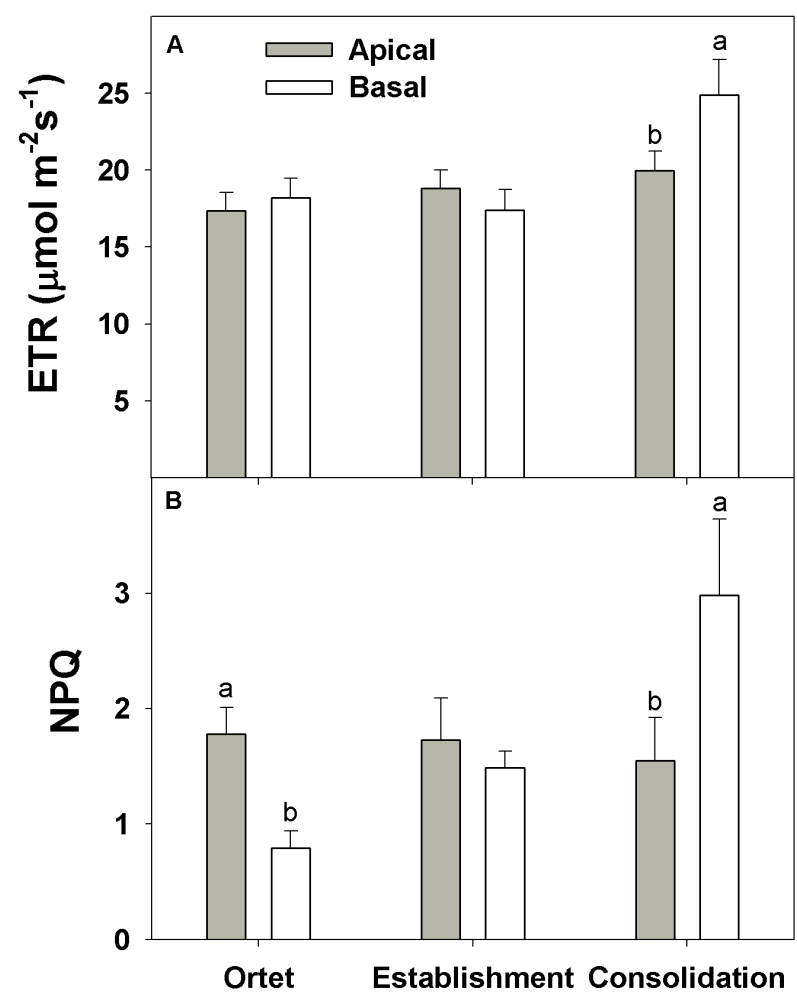

Figure 4. Electron transport rate trough PSII (ETR) (A) and non-photochemical quenching (NPQ) (B) of micrografts made from apical and basal shoot tips collected from adult $P$. radiate (9-year-old and ca. 8.8 $\mathrm{m}$ tall). Values showed in the ortet and during it in vitro micrograft establishment and consolidation phases. Mean \pm SE $(n=10)$. Different letters indicate significant differences between apical and basal shoot tips within each phase (Tukey test, $P<0.05$ ).

pacity, manifested through higher ETR and NPQ values. This higher photochemical activity is a proxy of higher $\mathrm{CO}_{2}$ assimilation capacity, and therefore of greater photosynthetic performance and potentially faster growth [18] [20] [21]. Additionally higher Fv/Fm reflects an ontogenetic age gradient of shoot tips morphogenic competence, where basal meristematic shoot tips present higher morphogenic capacities than apical ones [5] [6]. Finally, based on our results, we conclude that Fv/Fm can be an indicator of the micrograft's development according to the shoot tips position in the ortet and can be a useful indicator of the physiological stage of scions during micrograft transition from establishment to consolidation. This method is suggested to be suitable at low scale or laboratory characterization. It needs further scaling up if intended to use at larger scale such as productive forest nurseries.

\section{Acknowledgements}

The investigation was supported by MECESUP AUS 0103, MECESUP UCO 0214 grants. Materán MH thanks Universidad Nacional Experimental de Guayana-Venezuela and Escuela de Graduados Universidad de Concepción-Chile for scholarship. The Chilean National Commission of Scientific and Technological Research project PDA-24 through which RC was inserted into the academy.

\section{References}

[1] Menzies, M.I., Holden, D.G. and Klomp, B.K. (2001) Recent Trends in Nursery Practice in New Zealand. New Forests, 22, 3-17. http://dx.doi.org/10.1023/A:1012027013173

[2] Valledor, L., Hasbún, R., Meijón, M., Rodríguez, J., Santamaría, E., Berdasco, M., Feito, I., Fraga, M., Cañal, M. and Rodríguez, R. (2007) Involvement of DNA Methylation in Tree Development and Micropropagation. Plant Cell, Tissue and Organ Culture, 91, 75-86. http://dx.doi.org/10.1007/s11240-007-9262-z

[3] Fraga, M., Cañal, M., Aragonés, A. and Rodríguez, R. (2002) Factors Involved in Pinus radiata D. Don. Micrografting. 
Annals of Forest Science, 59, 151-157. http://dx.doi.org/10.1051/forest:2002002

[4] Rodríguez, R., Fernández, M., Pacheco, J. and Cañal, M. (2005) Envejecimiento vegetal, una barrera a la propagación. Alternativas. In: Sánchez, M. and Ríos, D., Eds., Biotecnología vegetal en especies leñosas de interés forestal, Concepción, Chile, 29-48.

[5] Cortizo, M., Alonso P., Fernández, B., Rodríguez, A., Centeno, M. and Ordás, R. (2004) Micrografting of Mature Stone Pine (Pinus pinea L.) Trees. Annals of Forest Science, 61, 843-845. http://dx.doi.org/10.1051/forest:2004081

[6] Fraga, M., Cañal, M. and Rodríguez, R. (2002) Phase-Change Related Epigenetic and Physiological Changes in Pinus radiata D. Don. Planta, 215, 672-678. http://dx.doi.org/10.1007/s00425-002-0795-4

[7] Sánchez-Olate, M., Zapata, J., Sáez, P., Ríos, D., Spiercolli, S., Álvarez, C., Delaveau, C. and Pereira, G. (2008) Competencia morfogénica de embriones maduros de Pinus radiata cultivados in Vitro y su relación con la posición del cono en el árbol. Bosque, 29, 212-216.

[8] Greenwood, M., Cui, X. and Xu, F. (2001) Response to Auxin Changes during Maturation-Related Loss of Adventitious Rooting Competence in Loblolly Pine (Pinus taeda) Stem Cuttings. Physiologia Plantarum, 111, 373-380. http://dx.doi.org/10.1034/j.1399-3054.2001.1110315.X

[9] Danthu, P., Hane, B., Sagna, P. and Gassama, Y. (2002) Restoration of Rooting Competence in Mature Faidherbia albida, a Sahelian Leguminous Tree, through Serial Root Sucker Micrografting. New Forests, 24, 239-244. http://dx.doi.org/10.1023/A:1021396814374

[10] Onay, A., Pirinc, V., Yildirim, H. and Basaran, D. (2004) In Vitro Micrografting of Mature Pistachio (Pistacia vera var. Siirt). Plant Cell Tissueand Organ Culture, 77, 215-219. http://dx.doi.org/10.1023/B:TICU.0000016822.71264.68

[11] Yildirima, H., Onayb, A., Süzererb, V., Tilkatc, E., Ozden-Tokatlid, Y. and Akdemird, H. (2010) Micrografting of Almond (Prunus dulcis Mill.) Cultivars “Ferragnes” and “Ferraduel”. Scientia Horticulturae, 125, 361-367. http://dx.doi.org/10.1016/j.scienta.2010.04.022

[12] Materán, M., Vega, M., Sánchez-Olate, M., Sáez, K., Rodríguez, R. and Ríos, D. (2008) Reactivación de material vegetal élite de Pinus radiata D. Don. mediante microinjerto in vitro. Interciencia, 33, 66-70.

[13] Valdés, A., Fernández, B. and Centeno, M. (2004) Hormonal Changes Throughout Maturation and Ageing in Pinus pinea. Plant Physiology and Biochemistry, 42, 335-340. http://dx.doi.org/10.1016/j.plaphy.2004.02.004

[14] Valdés, A., Centeno, M. and Fernández, B. (2004) Age-Related Changes in the Hormonal Status of Pinus radiata Needle Fascicle Meristems. Plant Science, 167, 373-378. http://dx.doi.org/10.1016/j.plantsci.2004.04.006

[15] Coopman, R.E., Reyes-Díaz, M., Briceño, V., Corcuera, L., Cabrera, H. and Bravo, L.A. (2008) Changes during Early Development in Photosynthetic Light Acclimation Capacity Explain the Shade to Sun Transition in Nothofagus nitida. Tree Physiology, 28, 1561-1571. http://dx.doi.org/10.1093/treephys/28.10.1561

[16] Coopman, R.E., Briceño, V.F., Corcuera, L.J., Bravo, L.A., Reyes-Díaz, M., Alvarez, D., Sáez, K., García-Plazaola, J.I. and Alberdi, M. (2011) Size and Light Availability Increase Photochemical Instead Non-Photochemical Capacities of N. nitida Trees Growing in an Evergreen Temperate Rain Forest. Tree Physiology, 31, 1128-1141. http://dx.doi.org/10.1093/treephys/tpr094

[17] Flexas, J., Bota, J., Escalona, J., Sampol, M. and Medrano, H. (2002) Effects of Drought on Photosynthesis in Grapevines under Field Conditions: An Evaluation of Stomatal and Mesophyll Limitations. Functional Plant Biology, 29, 461-471. http://dx.doi.org/10.1071/PP01119

[18] Baker, N.R. and Rosenqvist, E. (2004) Applications of Chlorophyll Fluorescence Can Improve Crop Production Strategies: An Examination of Future Possibilities. Journal of Experimental Botany, 55, 1607-1621. http://dx.doi.org/10.1093/jxb/erh196

[19] Flexas, J. and Medrano, H. (1999) Water Stress Induces Different Levels of Photosynthesis and Electron Transport Rate Regulation in Grapevines. Plant, Cell \& Environment, 22, 39-48. http://dx.doi.org/10.1046/j.1365-3040.1999.00371.x

[20] Murchie, E.H. and Lawson, T. (2013) Chlorophyll Fluorescence Analysis: A Guide to Good Practice and Understanding Some New Applications. Journal of Experimental Botany, 13, 3983-3998. http://dx.doi.org/10.1093/jxb/ert208

[21] Maxwell, K. and Johnson, G. (2000) Chlorophyll Fluorescence a Practical Guide. Journal of Experimental Botany, 51, 659-668. http://dx.doi.org/10.1093/jexbot/51.345.659

[22] Krause, H. and Weis, W. (1991) Chlorophyll Fluorescence and Photosynthesis: The Basics. Annual Review of Plant Physiology and Plant Molecular Biology, 42, 313-349. http://dx.doi.org/10.1146/annurev.pp.42.060191.001525

[23] Baker, N.R. (2008) Chlorophyll Fluorescence: A Probe of Photosynthesis in Vivo. Annual Review of Plant Biology, 59, 89-113. http://dx.doi.org/10.1146/annurev.arplant.59.032607.092759

[24] Genty, B., Briantais, J. and Baker, N. (1989) The Relationship between the Quantum Yield of Photosynthetic Electron Transport and Quenching of Chlorophyll Fluorescence. Biochimicaet Biophysica Acta, 990, 87-92. 
[25] Genty, B., Harbinson, J. and Baker, N. (1990) Relative Quantum Efficiencies of the Two Photosystems of Leaves in Photorespiratory and Non-Photorespiratory Conditions. Plant Physiology and Biochemistry, 28, 1-10.

[26] Álvarez, C., Sáez, P., Sánchez-Olate, M. and Ríos, D. (2012) Effects of Light and Ventilation on Physiological Parameters during in Vitro Acclimatization of Gevuina avellana Mol. Plant Cell, Tissue and Organ Culture, 108, 1-9.

[27] Carvalho, L., Osòrio, M., Chaves, M. and Amâncio, S. (2001) Chlorophyll Fluorescence as an Indicator of Photosynthetic Functioning of in Vitro Grapevine and Chestnut Plantlets under ex Vitro Acclimatization. Plant Cell, Tissue and Organ Culture, 67, 271-280. http://dx.doi.org/10.1023/A:1012722112406

[28] Sáez, P., Bravo, L., Sáez, K., Sánchez-Olate, M., Latsague, M. and Ríos, D. (2012) Photosynthetic and Leaf Anatomical Characteristics of Castanea sativa: A Comparison between in Vitro and Nursery Plants. Biologia Plantarum, 56, 15-24. http://dx.doi.org/10.1007/s10535-012-0010-9

[29] Sáez, P., Bravo, L., Sánchez-Olate, M., Latsague, M. and Ríos, D. (2012) Increased Light Intensity during in Vitro Culture Improves Water Loss Control and Photosynthetic Performance of Castanea sativa Grown in Ventilated Vessels. Scientia Horticulturae, 138, 7-16. http://dx.doi.org/10.1016/j.scienta.2012.02.005

[30] Huang, L., Weng, J., Wang, C., Kuo, C. and Shieh, Y. (2003) Photosynthetic Potential of in Vitro-Grown Juvenile, Adult, and Rejuvenated Sequoia sempervirens (D. Don) Endl. Shoots. Botanical Bulletin Academia Sinica, 44, 31-35.

[31] Sáez, P., Bravo, L., Sánchez-Olate, M., Latsague, M., Toneatti, M. and Ríos, D. (2013) Light Energy Management in Micropropagated Plants of Castanea sativa, Effects of Photoinhibition. Plant Science, 201, 12-24. http://dx.doi.org/10.1016/j.plantsci.2012.11.008

[32] Quoirin, M. and Lepoivre, P. (1997) Étude de milieux adpaté aux cultures in vitre de Prunus. Acta Horticulturae, 7, 437-442.

[33] Van Kooten, O. and Snel, J.F.H. (1990) The Use of Chlorophyll Fluorescence Nomenclature in Plant Stress Physiology. Photosynthesis Research, 25,147-150. http://dx.doi.org/10.1007/BF00033156

[34] McCullagh, P. and Nelder, J.A. (1989) Generalized Linear Models (Chapman \& Hall/CRC Monographs on Statistics \& Applied Probability). 2nd Edition, Chapman and Hall/CRC, UK.

[35] Quinn, G. and Keough, M. (2006) Experimental Design and Data Analysis for Biologists. Cambridge University Press, Edinburgh.

[36] Uribe, M., Delaveau, C., Garcés, M. and Escobar, R. (2008) Effect of Asepsis and Phytohormones on the in Vitro Establishment of Berberidopsis corallina from Nodal Segments. Bosque, 29, 58-64.

[37] Valdés, A., Fernández, B. and Centeno, M. (2003) Alteration in Endogenous Levels of Cytokinins Following Grafting of Pinus radiata Support Ratio of Cytokinins as an Index of Ageing and Vigour. Journal of Plant Physiology, 160, 1407-1410. http://dx.doi.org/10.1078/0176-1617-00992

[38] Materán, M., Fernández, M., Valenzuela, S., Sáez, K., Seemann, P., Sánchez-Olate, M. and Ríos, D. (2009) Abscisic Acid and 3-Indolacetic Acid Levels during the Reinvigoration Process of Pinus radiata D. Don Adult Material. Plant Growth Regulation, 59,171-177. http://dx.doi.org/10.1007/s10725-009-9400-1

[39] Pastenes, C., Pimentel, P. and Lillo, J. (2005) Leaf Movements and Photoinhibition in Relation to Water Stress in Field-Grown Beans. Journal of Experimental Botany, 56, 425-433. http://dx.doi.org/10.1093/jxb/eri061

[40] Valero-Aracama, C., Kane, M., Wilson, S., Anderson, V. and Philman, N. (2006) Photosynthetic and Carbohydrate Status of Easy and Difficult-to-Acclimatize Sea Oats (Uniola paniculata L.) Genotypes during in Vitro Culture and ex Vitro Acclimatization. In Vitro Cellular \& Developmental Biology-Plant, 42, 572-583. http://dx.doi.org/10.1079/IVP2006822

[41] Demmig-Adams, B. and Adams III, W.W. (1996) Xanthophyll Cycle and Light Stress in Nature: Uniform Response to Excess Direct Sunlight among Higher Plant Species. Planta, 198, 460-470. http://dx.doi.org/10.1007/BF00620064

[42] Horton, P., Ruban, A.V. and Walters, R.G. (1996) Regulation of Light Harvesting in Green Plants. Annual Review of Plant Physiology and Plant Molecular Biology, 47, 655-684. http://dx.doi.org/10.1146/annurev.arplant.47.1.655

[43] Valdés, A., Centeno, M., Espinel, S. and Fernández, B. (2002) Could Plant Hormones Be the Basis of Maturation Indices in Pinus radiata? Plant Physiology and Biochemistry, 40, 211-216. http://dx.doi.org/10.1016/S0981-9428(02)01371-2 


\section{Supplementary Material}

Table 1. Comparison of percentage of establishment and consolidation of $P$. radiata micrografts shoot tips collected from the basal and apical quarter of the ortet crown (9-year-old and ca. $8.8 \mathrm{~m}$ tall). Generalized lineal models and deviance analyses were used assuming Binomial error distribution. Significant differences were detected with the Wald statistic $P<0.05$ $(n=20)$.

\begin{tabular}{cccc}
\hline Source of variation & d.f. & Wald Stat. & $P$ \\
Intercept & 1 & 1.011480 & 0.314548 \\
Provenance within establishment & 1 & 4.762631 & $\mathbf{0 . 0 2 9 0 8 4}$ \\
Intercept & 1 & 0.789130 & 0.374363 \\
Provenance within consolidation & 1 & 0.000000 & 0.770604 \\
Intercept & 1 & 0.085022 & $\mathbf{0 . 0 2 3 9 6 3}$ \\
Apical between in vitro phase & 1 & 5.097302 & 0.3050007 \\
Intercept & 1 & 1.052173 & 1.000000 \\
\hline
\end{tabular}

Table 2. Comparison of Fv/Fm between apical and basal shoot tip provenance within each in vitro culture phases, respect to the ortet and between in vitro culture phases. Normality and homogeneity of variance were evaluated by KolmogorovSmirnov test $(P<0.05)$ and Levene $(P<0.05)$ tests. When appropriate, variables were transformed to follow the former assumptions.

\begin{tabular}{|c|c|c|c|c|c|}
\hline Source & Df & SS & MS & $\mathbf{F}$ & $\boldsymbol{P}$ \\
\hline \multicolumn{6}{|c|}{ Fv/Fm within establisment between provenance (In transformed) } \\
\hline Intercept & 1 & 3.176 & 3.176 & 1049.05 & $<0.001$ \\
\hline Provenace & 1 & 0.012 & 0.012 & 4.09 & 0.045 \\
\hline Error & 158 & 0.478 & 0.003 & & \\
\hline \multicolumn{6}{|c|}{ Fv/Fm within consolidation between provenance (In transformed) } \\
\hline Intercept & 1 & 7.070 & 7.070 & 939.52 & $<0.001$ \\
\hline Provenace & 1 & 0.212 & 0.212 & 28.18 & $<0.001$ \\
\hline Error & 218 & 1.640 & 0.008 & & \\
\hline \multicolumn{6}{|c|}{ Fv/Fm ortet vs. 1thr day in vitro of apical scions } \\
\hline Intercept & 1 & 13.358 & 13.358 & 14851.61 & $<0.001$ \\
\hline in vitro introduction & 1 & 0.001 & 0.001 & 1.23 & 0.281 \\
\hline Error & 18 & 0.016 & 0.001 & & \\
\hline \multicolumn{6}{|c|}{ Fv/Fm ortet vs. 1thr day in vitro of basal scions } \\
\hline Intercept & 1 & 13.561 & 13.561 & 13778.41 & $<0.001$ \\
\hline in vitro introduction & 1 & 0.008 & 0.008 & 8.41 & 0.010 \\
\hline Error & 18 & 0.018 & 0.001 & & \\
\hline \multicolumn{6}{|c|}{ Fv/Fm establisment vs. consolidation of basal scions } \\
\hline Intercept & 1 & 2.023853 & 2.023853 & 442.153 & $<0.001$ \\
\hline Phase of in vitro culture & 1 & 0.004161 & 0.004161 & 0.9091 & 0.343 \\
\hline Error & 97 & 0.443991 & 0.004577 & & \\
\hline
\end{tabular}




\section{Continued}

Fv/Fm establisment vs. consolidation of apical scions

Intercept
Phase of in vitro culture
Error

$\begin{array}{ccccc}1 & 3.212842 & 3.212842 & 598.9765 & <0.001 \\ 1 & 0.352417 & 0.352417 & 65.7019 & <\mathbf{0 . 0 0 1} \\ 97 & 0.520297 & 0.005364 & & \\ & \text { MS Effect } & \text { MS Error } & \text { F } & \boldsymbol{P} \\ & 0.010 & 0.001 & 9.029 & 0.053 \\ 0.038 & 0.002 & 8.298 & 0.050 \\ 0.000 & 0.000 & 1.027 & 0.324 \\ 0.000 & 0.000 & 0.021 & 0.886 \\ 0.011 & 0.001 & 9.329 & 0.050 \\ 0.040 & 0.002 & 8.984 & 0.049 \\ & & \mathbf{d} & \boldsymbol{P} \\ & & 0.105 & >0.20 \\ & & 0.200 & <0.20 \\ & & & & \\ & & 0.128 & >0.20 \\ & & 0.109 & >0.20 \\ & & 0.114 & <0.20 \\ & & & <0.10\end{array}$

Fv/Fm establisment vs. consolidation of apical scions (ln transformed)

Table 3. Comparison of light energy partitioning between apical and basal shoot tip provenance in the ortet and within each in vitro culture phases. Normality and homogeneity of variance were evaluated by Kolmogorov-Smirnov test $(P<0.05)$ and Levene $(P<0.05)$ tests.

\begin{tabular}{|c|c|c|c|c|c|}
\hline Source & Df & SS & MS & $\mathbf{F}$ & $\boldsymbol{P}$ \\
\hline \multicolumn{6}{|c|}{ ETR in the ortet } \\
\hline Intercept & 1 & 6315.632 & 6315.632 & 405.967 & $<0.001$ \\
\hline Provenance & 1 & 3.528 & 3.528 & 0.227 & 0.640 \\
\hline Error & 18 & 280.026 & 15.557 & & \\
\hline \multicolumn{6}{|c|}{ ETR in the establishment } \\
\hline Intercept & 1 & 6553.217 & 6553.217 & 414.108 & $<0.001$ \\
\hline Provenance & 1 & 10.083 & 10.083 & 0.637 & 0.435 \\
\hline Error & 18 & 284.848 & 15.825 & & \\
\hline \multicolumn{6}{|c|}{ ETR in the consolidation } \\
\hline Intercept & 1 & 10051.577 & 10051.577 & 299.880 & $<0.001$ \\
\hline Provenance & 1 & 118.476 & 118.476 & 3.535 & 0.046 \\
\hline Error & 18 & 603.336 & 33.519 & & \\
\hline \multicolumn{6}{|c|}{ NPQ in the ortet } \\
\hline Intercept & 1 & 32.903 & 32.903 & 92.567 & $<0.001$ \\
\hline Provenance & 1 & 4.862 & 4.862 & 13.680 & 0.002 \\
\hline
\end{tabular}




\section{Continued}

Error

NPQ in the establishment

Intercept

Provenance

Error

NPQ in the consolidation

Intercept

Provenance

Error

Levene's test for homogeneity of variances

ETR in the ortet

ETR in the establishment

ETR in the consolidation

NPQ in the ortet

NPQ in the establishment

NPQ in the consolidation

Kolmogorov-Smirnov test for normality

ETR in the ortet

ETR in the establishment

ETR in the consolidation

NPQ in the ortet

NPQ in the establishment

NPQ in the consolidation

$6.398 \quad 0.355$

18

51.833

51.833

107.537

0.292

0.607

$<0.001$

0.292

0.482

18

8.676

1

102.622

102.622

66.082

0.000

1

10.227

10.227

6.585

0.019

18

27.953

1.553

MS Effect

MS Error

4.257

\section{F}

P

0.057

1.709

5.865

0.013

0.909

36.745

10.202

0.291

0.596

0.187

0.096

3.602

0.074

1.831

11.142

1.954

0.179

0.829

0.248

4.873

0.051

$3.347 \quad 0.084$

d

$\boldsymbol{P}$

$0.105>0.20$

$0.200>0.20$

$0.128>0.20$

$0.109>0.20$

$0.189>0.20$

$0.201>0.20$ 
Scientific Research Publishing (SCIRP) is one of the largest Open Access journal publishers. It is currently publishing more than 200 open access, online, peer-reviewed journals covering a wide range of academic disciplines. SCIRP serves the worldwide academic communities and contributes to the progress and application of science with its publication.

Other selected journals from SCIRP are listed as below. Submit your manuscript to us via either submit@scirp.org or Online Submission Portal.
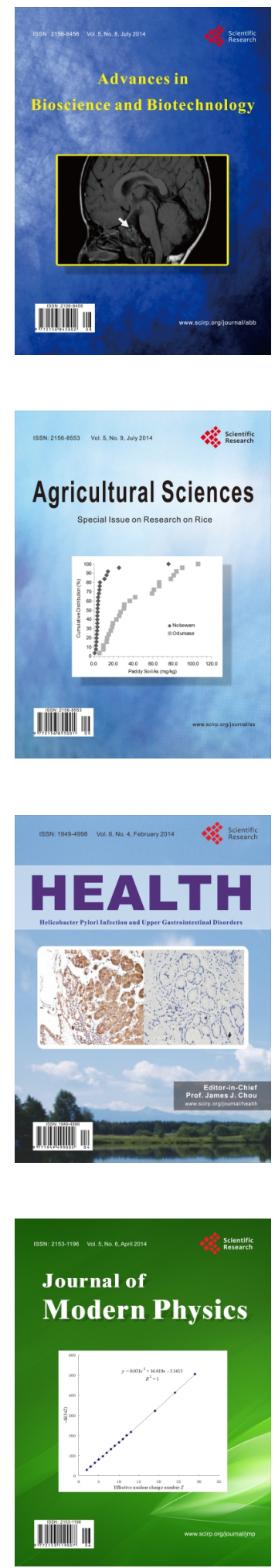
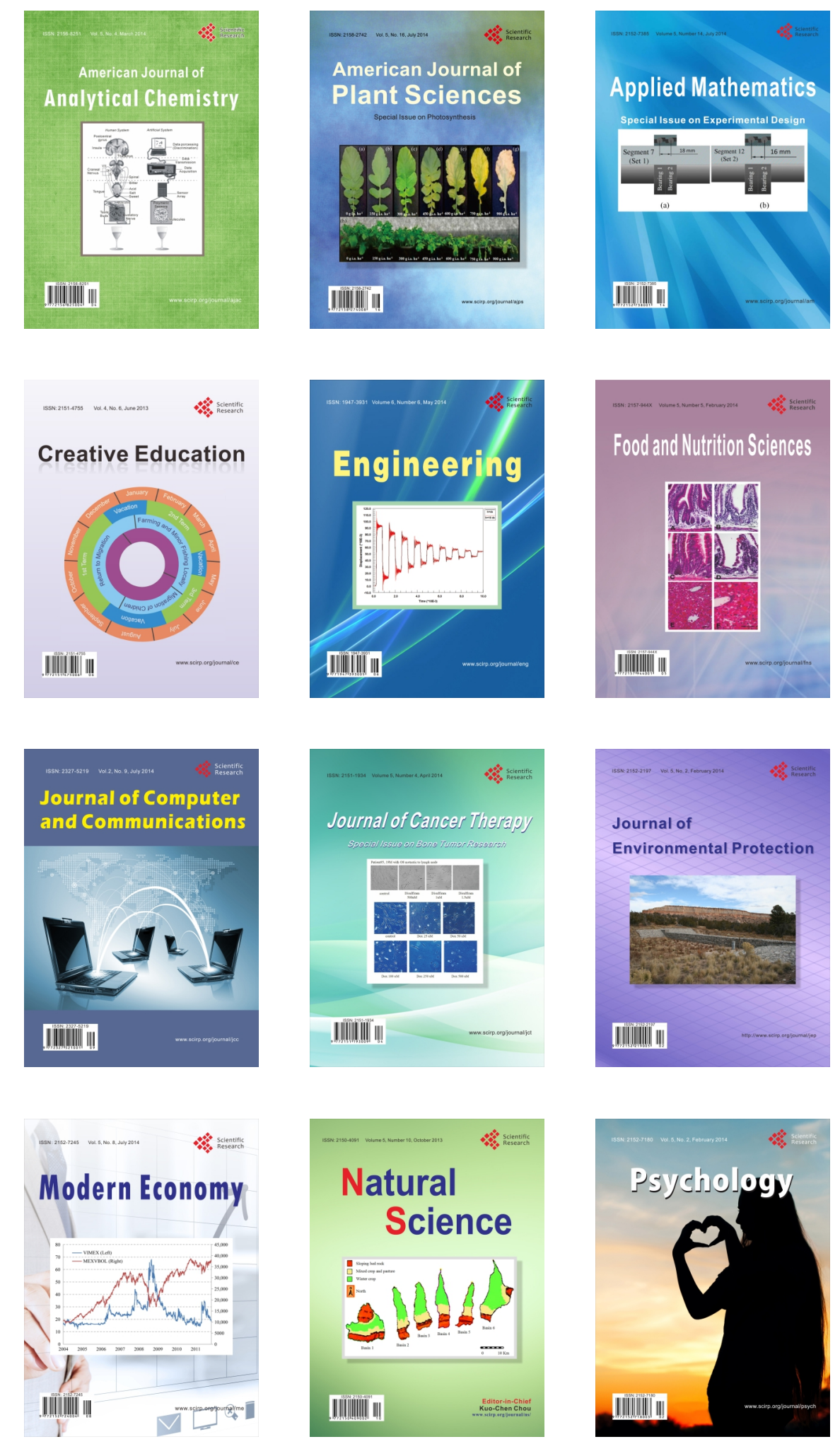